\title{
Pentecostal talk about God: Attempting to speak from experience
}

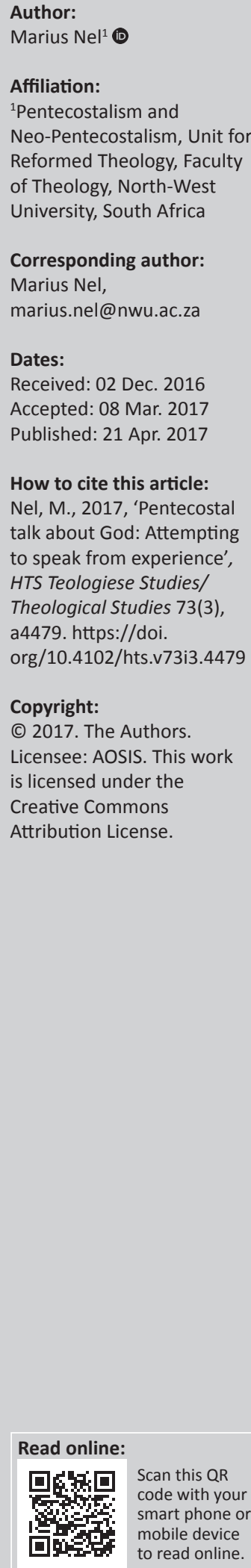

Pentecostals have their own ethos to bring to the theological table. Although they represent a diverse spectrum of beliefs, they share a basic preference for experience co-determining their theology, along with their interpretation of Scripture. Their hermeneutical viewpoint since the 1970s that links them with that of early Pentecostals allows them to regard the Bible as the inspired Word of God with authority for their lives although they qualify that statement by adding that encounters with God within the faith community in ways similar to those recorded in the Bible is conditional for understanding and interpreting biblical accounts of God and God's faith community. It is proposed that Pentecostals need to develop a perspective on the all-inclusive difference made by their experience of God in all areas of their lives. Their experience of God through his Spirit shifts their loci communes and theological method. It is argued that Pentecostal theology should rethink every aspect of theological enterprise through the lens of the reality of God's encounter with human beings as experienced in the faith community. In the last section, this is demonstrated in terms of one subject, of God as the object of theology.

\section{Introduction}

Pentecostals represent a diverse spectrum of beliefs and practices. ${ }^{1}$ However, they share a basic preference for experience as a precondition for formulating doctrine and theology, based on a hermeneutical lens that allows them to read the Bible in a specific way. And from their experience they speak about God in a certain way that one can perhaps call 'Pentecostal talk' (cf. AsamoahGyadu 2012:66).

While a significant part of Pentecostals approach the Bible in a fundamentalist manner as a result of earlier cooperation with conservative Evangelicals in Pentecostals' need for acceptance by the community and government from the $1940 \mathrm{~s}^{2}{ }^{2}$ another large grouping considers the function of the Bible in other terms that relate to the preference of the earliest Pentecostals (Karkkainen 1998:76-115; Lewis 2001:5; Stevens 2006:287). ${ }^{3}$ Fundamentalists regard the Bible as the absolute and foundational authority against which all other truth-claims about life in general, including science and medicine, as well as the Christian faith in particular should be measured. The a priori assumption is that the Bible is the inspired and therefore perfect and infallible Word of God. In contrast, Pentecostals have never been content with only affirming the 'truthfulness' of biblical accounts of God and his dealings with humankind, limiting their formulation of doctrine to the information contained within the Bible (Ellington 2001:245). From the earliest days of the movement they maintained that encounters with God within the faith community in ways similar to those recorded in the Bible, and described in terms of biblical language, form the precondition for speaking about God at all. That the events of the Bible should be appropriated in terms of contemporary experience is non-negotiable for them. ${ }^{4}$ The difference, they argue, is that encounters lead to first-hand reports and a hands-on 1.Johns (2007:59) reckons there are 11000 Pentecostal and charismatic denominations worldwide

2.Fundamentalists view their task as to defend orthodox Christianity against those who were attempting to accommodate the faith to the realities of the modern world. They also observe a rigorous lifestyle that often precludes social, economic and political activity from the members of the community of faith. For Pentecostals, these practises were easy to embrace (Alvarez 2014:77; Fries 1996:11-22; Marsden 2006:43-47). Evangelicalism is defined as the theological system that resulted from the synthesis of churches forming the National Association of Evangelicals in 1942, with its main concern being the communication of the gospel to the whole world, calling individuals to personal faith in Christ (Lewis 2001:3; Railey \& Aker 2007:50).

3.Noel (2007:25) encourages Pentecostals to continue in the hermeneutical traditions of their early leaders if they wish to remain relevant in the future. What they need is a pneumatological hermeneutic consisting of the best values of early Pentecostal hermeneutics as well as of postmodernism.

4.This allows for subjectivity in the process of interpretation. Johns (2007:211) in his criticism of Pentecostal epistemology emphasises that the Holy Spirit does not offer experience without truth. However, Pentecostals view truth primarily as a person, Jesus Christ, and confess that truth is to be found in a living and growing relationship with him. 
theological enterprise based on own experience as viewed through the lens of biblical accounts (cf. Köstenberger 2012:7). ${ }^{5}$

\section{Pentecostal hermeneutical angle}

It is not clear whether it is possible to speak of a distinctive Pentecostal hermeneutics that is qualitatively different from other theological traditions. ${ }^{6}$ However, Pentecostals regard the Bible as the inspired Word of God with authority for their lives although they qualify that statement with the addition that encounters with God within the faith community in ways similar to those recorded in the Bible is conditional for understanding and interpreting biblical accounts of God and God's faith community (Ellington 2001:245). The implication is clear, that the truth-claims made by the Bible are not only conceptual but also experiential in nature. ${ }^{7}$ Theological enterprise should not only be based on data provided by the Bible but also supplemented with contemporary experience that supports biblical data and may even go further (in expectation of Jesus' promised 'greater works'). Theology is best done when authority is granted to the Bible, and the revealed Word of God is mediated to believers by the Spirit (Mei 2001:16). The experience of individuals who are prompted and directed by the Spirit contributes to understanding the revelation, but in all cases, the testimony of the Bible should be viewed as a sufficient rule for faith and practice (Railey \& Aker 2007:45). ${ }^{8}$

To claim that God speaks and acts today as he did in biblical times through his Spirit is problematic for two groups of people, those who support a cessasionist view that the extraordinary revelations of the Spirit ceased at the end of the apostolic age (Huckle 2009:74; Ruthven 1969:3) and others using a scientific worldview that precludes what they perceive as pre-modern and pre-scientific biblical

\begin{abstract}
5.This also allows them to leave room for 'Pentecostal talk' that progresses further 5ecause Jesus says in the context of his healing on a Sabbath of an invalid at the because Jesus says in the context of his healing on a Sabbath of an invalid at the
bath of Bethesda according to John 5:19-20 that he can do nothing of his own accord but only what he sees the Father doing. And the Father will show him greate works to do. And in John 14:9-12, when Philip asks Jesus to show them the Father, Jesus responds that he is in the Father and the Father is in him, and whoever has seen him has also seen the Father. He then adds that whoever believes in him will also do the works that he has done, and greater works than these will he do,

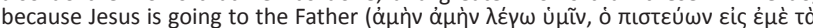

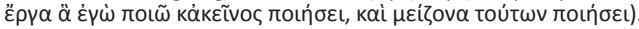

6.Ervin (1979:113) was convinced that a distinctive Pentecostal hermeneutic can be defined; he called it 'pneumatic exegesis' consisting of an intuitive, non-verbal communication between God and man. Arrington (1988:376) supports his viewpoint. Cargal (1993:173) rejects the possibility on the basis that it is based on a viewpoint. Cargal (1993:173) rejects the
too simple, naive positivistic worldview.

7.On the one hand, 'there can be no basic difference between the truth the Christian community knows through the indwelling of the Holy Spirit and what is set forth in Scripture' (Williams 1988:22-23) while on the other hand prepositional truths only take on vitality and force when they are confirmed and illustrated in the living experiences of devout disciples of Christ (Railey \& Aker 2007:44). Pentecostals take seriously the working of the Spirit to verify the truths as real and empower thei proclamation. However, the experience brought by the working of the Spirit is secondary to the Bible in status of authority, invalidating the charge that Pentecosta theology is solely experience based (Railey \& Aker 2007:50).

8.The Spirit is not 'a vapour or an influence, as many suppose', but a real person going forth from the Father and the Son, and serving on their behalf, as God himself imparted to work in his children, empowering the words of the Bible, making his grace available to them, helping their infirmities, witnessing to their salvation and carrying into effect the divine administration of the kingdom (Taylor [1907]2006:59). The Spirit enables them to understand the Scriptures and to perceive spiritual The Spirit enables them to understand the Scriptures and to perceive spiritual
things (Taylor [1907]2006:61). George F. Taylor (1881-1934) was a pioneer leader in things (Taylor [1907]2006:61). George
the early Pentecostal Holiness church. (and contemporary) descriptions of so-called supernatural interventions, including miracles. ${ }^{9}$

Pentecostals' worldview allows for the continuing revelation of God. They expect to hear from him and to experience his power in their daily lives. They are neither materialists, believing that nothing exists except matter and its laws, nor rationalists, but they recognise the reality of the supernatural realm (Railey \& Aker 2007:55). And they define truth in terms of their personal relationship with him, based on what the Bible leads them to expect. Pentecostal hermeneutics bases truth in the Bible, viewed as testimonies of God's interaction with people and providing the language to describe contemporary experiences of this interaction and providing the basis of what contemporary believers may expect to experience with and from God (Dela Cruz 2010:100).

Experiencing God is defined in terms of internal renewal through experiences of encounter as well as external experiences through the manifestation of God's miraculous speech and action in the form of healings, deliverance, et cetera (McClean 1984:49). These internal and external experiences of God are foundational to a Pentecostal understanding of the knowledge of God, providing a mode of God's presence and activity in biblical times as well as in the here and now that is ontologically the same (Karkkainen 1998:76-81; McClean 1984:47). ${ }^{10}$ Evangelicalism, on the contrary, defines it as ontologically different because it has adopted the basic presuppositions of a scientific worldview, forcing them to reject as invalid all the many cases of God's acting and speaking (Gilkey 1961:203). For this reason, the historical-critical method plays a key role in the majority of Evangelical hermeneutical efforts (Noel 2007:18, fn. 22). The result is that they accept the general truth about God but deny all the particular cases, whether in biblical or contemporary times, on the basis of which the generalisation was first made. This leads to what Ellington (2001:248) defines as a kind of linguistic schizophrenia in which Evangelicals continue to use biblical and orthodox theological language of divine activity and speech, while they have dispensed with the wonders, miracles and revelations that gave meaning and content to these theological words, like 'God acts' and 'God speaks' (Gilkey 1961:199).

The divergence between conservative Christians and Pentecostals is primarily an epistemological one, involving a difference in the way in which they know, experience and

\footnotetext{
9.It should be kept in mind that the Pentecostal church grows primarily among people in the non-Western world who have not been immersed for centuries in the culture of modernity, with the modern scientific worldview and the secular mentality that accompany it. This new religious orientation is also appealing to significant numbers of those in the Western world who, having been brought up on this worldview, are now rejecting it or at least seeking to experience dimensions of reality excluded by it (Shaull 1998:9).

10.Contemporary elevation of experience to authority status began with Friedrich Schleiermacher (1768-1834) who argued that the ground of Christianity was religious experience, an experience which became the authoritative determinant for theological truths. However, experience as such is not accepted by Pentecostals as the source of authority; it is always experience married to Scripture because experiences vary and their causation is not always clearly discernible (Bloesch 2005:13; Railey \& Aker 2007:44). What is needed is a reliable authority source that exists beyond variables and may even contradict and correct experience if need be. Experience alone mediating the revelation of God to people is not reliable (Brown Experience
1974:48).
} 
receive revelation from God. To describe their perception of revelation, Pentecostals need a specific language because they experience God in relational terms (Ellington 1996:19). ${ }^{11}$

Their experience of God is based on and defined in terms of biblical accounts, leading to the question about the status of the Bible in Pentecostal circles. They build their hermeneutics on the assumption that the Bible is infallible (Van der Laan 1989:32, fn. 42) but recognise at the same time that they are not able to demonstrate its infallibility. Neither do they take responsibility to do so but rather link the Bible's infallibility to its inspiration by God, who is infallible. They argue that no further demonstration of its infallibility is either necessary or possible (Arrington 1988:382). Any direct participation by God in biblical accounts falls outside the range of modern scientific investigation; his speaking, acting and revealing is not so much unscientific as ascientific. In other words, divine encounters are hardly accessible to examination using conventional historical methods.

Pentecostals view knowledge about God not as a cognitive recognition of a set of precepts and doctrines, as is the case in many other theological traditions, but rather as a relationship with the One who defined those precepts by which Christians tend to order their lives (Arrington 1988:382). 'Knowledge' is insight into divine truth, the gift which believers need to understand the Bible (Taylor [1907]2006:64). The precondition for participation in Pentecostal theology is then belief in God and his current revelation to the faith community (King 2008:73). ${ }^{12}$

Truth in Pentecostal practice is located in the contribution of believers to the worship service and evangelisation by way of testimonies that require the recalling of memory. This is based on what they perceive as the biblical precedent where truth is generated by the testimonies of witnesses. Brueggemann (1997:206) states that the central truth-claims of Israel in the Old Testament is not a declaration of historical facts, but it is offered as a testimony by witnesses. Biblical truth for him is not located in the historical events underlying the offered testimony, but in the testimony itself. When believers make theological constructions from the Old Testament, they have access only to the testimonies itself (Dela Cruz 2010:114). These testimonies are necessarily

11.Pentecostals are not unique in their experience of God. Many others also use relational language to describe their experience of revelation. In the article, however, Pentecostals are contrasted with some conservative Christians by way of argument Jacobsen (2006:5) adds that it is also not necessarily their experience that set Pentecostals apart; it is the way those experiences are theologically categorised and defined. Others have also experienced the power of the Spirit, God's miraculous ability to heal and speaking in tongues, but what makes Pentecostals different is the way the movement talks about those experiences, naming them and buldling them together in ways that other groups do not.

12.Theology is defined here as a human construction of our reflection on God and his relationship with human beings, based on the primary event of the revelation of God recorded in the Bible and on the secondary event of the Spirit's revelation of God based on the appropriation of that primary event in the lives of contemporary believers. In this sense, Pentecostal theology is a second-order reflection on the primary narrative of the revelation of God coordinated with the experience of that primary narrative of the revelation of God coordinated with the experience of that revelation by contemporary readers, and their reflection about that experience (Grenz 1993:73; Migliore 1991:9; Pinnock 1990:182; Railey \& Aker 2007:45). To state that theology is virtually absent from the Pentecostal movement because their stress on the emotive stands in contrast to the intellectual is not true, as can be seen by the quantity and quality of publications from Pentecostal theologians. The popular stereotype is wrong (Jacobsen 2006:5). coloured by the subjectivity of the witnesses (Castelo 2004:53), and the authority of the witnesses is based on nothing more and nothing less than the willingness of the community to credit, believe, trust and take this testimony seriously (Brueggemann 1997:68). ${ }^{13}$

The primary mode of appropriation by the faith community that today reads those Scriptures that contain the truths proposed by biblical witnesses is not an ascension to the historical truthfulness of the information reflected in the biblical narratives but lies in the faith community perceiving the capacity of the text to generate, evoke and articulate alternative images of reality (Brueggemann 1997:68) and, for Pentecostals, generate similar encounters with God (Ukpong 1984:523). ${ }^{14}$ Believers experience that God uses the text to create a new vision of how the world could and should be, inspiring them to campaign for the coming of the kingdom of God (Ellington 2001:257). In this way, tales in biblical narratives are tested against lived experience, an essential element of a Pentecostal community's appropriation of the truth-claims of Scripture. In other words, the text is reexperienced by contemporary readers as a precondition for interpreting it correctly and reappropriating its meaning (Byrd 1993:210). Appropriation is only possible when the text is evaluated and interpreted in light of new experience; the congregants evaluate the sermon's explication and application of biblical truths on the same grounds (Goldingay 1997:7).

\section{Pentecostal talk about God}

The implication is that Pentecostals have their own ethos to bring to the theological table (Cross 2000:29). Pinnock (2000:22) argues that they have the perfect ingredients for a theological recipe in their own worship and lives that allow them to speak authoritatively about God. They have something important to share with others out of their own experience with God. ${ }^{15}$ Because their spirituality is dynamic and not merely rationalist, they can see and appreciate the relationality of God, perhaps more than theologians from other traditions. And because they are 'simple readers of the Scripture', they take the 'natural' sense of the narrative and read the Bible as the story world of God interacting with humans. Archer (2004:189-191)

13.It should be qualified that Pentecostals do not support ecclesiastical authority as such if it holds that the church itself must be the final authority in all matters of faith and practice, and the interpretation by the church is limited to those who are specially trained and chosen for that task, whose labour is usually promulgated in sreedlike statements that over time become authoritative (Railey \& Aker 2007:43). In the context of the Pentecostal congregation, every believer is valued as a In the context of the Pentecostal congre
participant in realising the Word of God.

14.McClean (1984:50) states in this regard that Pentecostals understand the mode of God's presence among his people in conjunction with their use of Scripture, resulting in a Pentecostal hermeneutic and theology that at major points are different from an orthodox non-Pentecostal hermeneutic and theology.

15.In the past, Pentecostal theology consisted mainly of using themes borrowed from evangelical theology and tacking on some issues emphasised by Pentecostals, like the Spirit, spiritual gifts and spiritual fruit, which were viewed as distinctive (as demonstrated by the well-used text book of systematic theology prepared by lecturers of the American Assemblies of God, Horton 1994). The motivation was that it is unnecessary for Pentecostals to reinvent the theological wheel. Another that it is unnecessary for Pentecostals to reinvent the theological wheel. Another tradition among Pentecostals is anti-intellectualist, suggesting that the free movement of the Spirit and theological enterprise exclude one another Theological endeavours of some Protestant traditions were viewed as dry and lifeless because it was undertaken within what was perceived as a rationalist vacuum, devoid of the breath of the Spirit (Cross 2000:33). Cf. Bowdle's (2000:10) remark, 'Pentecostals must make peace with the academy and understand that Jesus is Lord of learning, too'. 
argues that Pentecostals require a hermeneutical strategy that involves an interdependent tridactic dialogue between Scripture, the Spirit and community, resulting in a creative negotiated meaning with the readers in the community, the story world of the text and the leading of the Holy Spirit being participants in the tridactic negotiation for meaning. ${ }^{16}$ They tend to engage with the narrative in a literal and existential sense (Pinnock 2000:9). An important part of their Bible reading practice is that they then expect that something in the same vein as described in the biblical narrative would happen to them in terms of God's ongoing interaction with human beings. They expect to encounter God as part of their reflection on Scripture, playing into an open, relational concept of God. Their theology then follows their experience and not the other way around as in some other theological traditions (Johns 1995:4). They know and experience God in the existential reality of daily living and construct their theological understanding of God from this experiential reality. They do not get involved with philosophical speculation about the nature and will of God because their God is not devoid of existential meaning but teeming with life and interacting on a regular basis with his children (Pinnock 2000:21). Their model allows for God who intervenes and speaks in their lives in surprising ways rather than God characterised by static perfection.

Pentecostal talk allows for God who interacts with his creation by hearing and responding to prayers rather than God being a deistic force that is eternally distant from creation. They view God in this way because that is how they perceive him in Scriptures, and their experience of God verifies their developing theology (Cross 2000:32).

Pentecostals share many tenets in common with Christians from other traditions but they have experienced God in ways that others do not confess. Where in some cases they have viewed theology in the past as a discussion of their distinctives, what is needed is rather that a perspective be developed on the all-inclusive difference made by their experience of God in all areas of their lives. Their experience of God through his Spirit shifts their loci communes and theological method (Siekawitch 2009:23). They are not just Evangelicals who speak in tongues; they live and think in terms of their charismatic experience. In that sense, Menzies (1979:14-15) is not correct when he argues that Pentecostal theology is based on the common truths found in Evangelicalism with the addition that it emphasises a place for the ministry of the Spirit. The argument is conducted here that Pentecostal theology should rethink every aspect of theological enterprise through the lens of the reality of God's encounter with human beings as experienced in the faith community.

That this is not the case at the moment can be seen from a perusal of literature produced by Pentecostal theologians.

16.'A person who is taught by the Spirit has an internal manifestation of an insight into the words of Jesus (John 14:26), and an external manifestation of wisdom, especially in regard to the Christ-life, and the hidden things of God ...' (Taylo [1907]2006:62).
What is needed is the development of a theological method that would be commensurate with its experience of God, leading to serious reflection not only about the Spirit and his work in believers but also of all aspects of theology. Land (1993:25-27) suggests that Pentecostal spirituality is not merely emotional and non-cognitive, limiting experience to the realm of the affections (contra researchers like Spittler, Williams and Hollenweger) but that affections and mind must be married in spirituality, forming the basis for Pentecostal spirituality (contra other traditions that rely heavily or exclusively on the cognitive for theological endeavours).

In his Evangelical Theology, Barth (1979:55) makes the same proposal that evangelical theology cannot be but pneumatic, spiritual theology because it is only in the realm of the power of the Spirit that theology can be realised as a free, critical and happy science of the God of the gospel. 'Only in the courageous confidence that the Spirit is the truth does theology simultaneously pose and answer the question about truth' (Barth 1979:55). Pentecostal theology should overcome the modernist split between reason and affections, and cognition and experience, engaging the whole person within the communion of charisms, forming a worshipping, witnessing, reflective whole where at the heart of the community lies the liturgical life (Land 1993:34). ${ }^{17}$

This does not imply that theology should be relegated in order to be subordinate to spirituality. Then theology is truncated to become a commentary on experience. But to argue that theology should be devoid of spirituality is unacceptable for Pentecostals because their encounter with God lies at the heart of their religious practice and its resultant reflection about it (Plüss 2003:5). Spirituality consists of God and his relationship with his people and that forms the heart of their theological endeavours as well (Johnson 1988:12). How one experiences God influences the way one reflects on God (Cross 2000:35); for Pentecostals, experience is primary over theory and must in all cases inform cognitive packaging of theology (Pinnock 2000:10-11), making Pentecostal theology dynamic not rationalistic (Pinnock 2000:4). Their theology should always be based upon Scripture as the original source but at the same time they believe God speaks to his church through the gifts of the Spirit to correct, edify and comfort (Railey \& Aker 2007:55). Theology may not be a mere restatement of propositional truths, even though in contemporary language. It should be a critical reflection on the primary truth of the biblical narrative, shaped by the language of the Bible but not equated with the Bible because the truth should first be made real in the lives of contemporary readers by the witness of the Spirit before the biblical truth can be interpreted and appropriated (Migliore 1991:xii). Otherwise the philosopher Richard Rorty's complaint may become valid, that it is pictures rather than propositions, metaphors rather than statements, which determine most of our convictions, and language then no longer serves as a

17. Reason serves as a good servant of the revelation of God but is not a good master over that revelation, in the words of Railey and Aker (2007:45). 
mirror of metaphysical reality but as a tool for edification and aesthetic enrichment (Bloesch 2005:16-17).

Pentecostal theology is experience-certified theology, a theology that through faith and obedience becomes a Biblebased 'experience-reality' (Erickson 1985:21). Theology exists to serve the revelation of God to human beings and not the other way around (Pinnock 1990:182). And it serves as the interpretation of biblical narrative to foster a response within the faith community to the revelation of God. For that reason, theology cannot be an enterprise taking place in the exclusive atmosphere of the proverbial ivory-tower but can only be the life-giving activity that defines it within the community of faith, providing them with a coherent reflection on the revelation of God. Effective theology is measured in terms of the effects of the sermon, in people getting saved and healed, baptised in the Spirit and encouraged through the specific Word of God (Byrd 1993:203-204). The two elements conditional for good theology are the interpretation and appropriation of the biblical narrative and God's Spirit driving home the truth contained in that narrative. The Spirit confronts a person with the reality of God in the biblical narrative and in one's present situation, affecting a cognitive and emotive response to the event (Pinnock 1990:186). ${ }^{18}$

\section{Pentecostals and God}

Pentecostals view God in trinitarian terms, and the doctrine of the Trinity not as a doctrine about the abstract nature of God but about his life with human beings and the resultant shift in relationships between human beings (LaCugna 1991:1). Trinitarian theology per se is a theology of relationships, concerned with communion and love, forgiveness and courtesy (Yong 2015:35). God is viewed as a being whose fundamental feature is loving relationality (Joubert 2013:122). As the God who chooses to stand in relationship with human beings, he risks his future and reputation with humanity as he becomes involved with the sordid detail of believers' (and non-believers') lives. As Father, Son and Spirit relate lovingly among themselves as a personal, communicative God from all eternity, God also relates to humans (McRoberts 2007:161). The trinitarian relational model of God suits Pentecostal experience and life (Zizioulas 1997:12), providing a model for thinking about God, and the personality of human beings with its source in the Trinity (Schaeffer 1990:283). And the faith community forming the church can also only be described in valid terms on the model of trinitarian relations (Volf 1998:7). At the same time, reason discovers a stumbling block when confronted with the paradoxical character of trinitarian theology but 'since it is based on clear Scripture, reason must be silent at this point and we must believe' (Luther in Althaus 1966:199). The role of reason is ministerial, never magisterial or rationalistic in relation to God and the Bible (McRoberts 2007:140).

18.A part of contemporary theology suffers from the uncertainty in stating anythin with self-assurance as the truth as the direct result of postmodernism's disapproval of any form of unified knowledge and absolute truth. For a Pentecostal attempt to define theology as an academic discipline, cf. Yong (1998).
Barth influenced Pentecostal theology in a distinctive way, probably more than any other theologian of the 20th century (Becker 2004:45). Barth (1957:284) states that we learn what it means to be a person and how to stand in relationships to other persons from God himself. The absolute, immutable, changeless, timeless, impassible God is also the personal God who answers prayer and seemingly changes his mind. For Pentecostal thinking, the paradox contained in biblical descriptions of God does not pose any problems because they experience God in dynamic, personal terms as the unknowable God who in his greatness, might and majesty as Master of the universe falls outside the frame of reference of human beings, who are the works of his hands. What is important in Pentecostal theology is not to say much about God but to love him (Yong 2002:23). He is experienced as the God who engages in dialogue with his children, a living person who responds to his children's adoration and worship by encountering them with his grace and provision (Pinnock 2000:20). ${ }^{19}$

It falls outside Pentecostals' experience that God can be contained in absolutist and unchangeable, philosophical (Greek, Aristotelian) categories (such as 'unmoved mover', 'cause of all being', 'pure being' or 'world soul') although they have to admit that philosophical terminology may be useful in describing their experience (McRoberts 2007:143). Theology can not only reiterate what the Bible states; it needs language to describe its object of investigation and reflection. However, it must be realised that language can never adequately express the One that theology endeavours to picture (Tollefsen 2014:59). Theology should be based on biblical language but it needs to remain relevant and faithful by utilising philosophical mechanisms in its work (Tollefsen 2014:60).

Barth (1957:329) argues that theology became nominalistic when the attributes of God were described as 'names' given to describe God, or were human perceptions of God that do not correspond to any reality in him. The essentia [essence] of God was viewed as the reality of God. The attributes or perfections of God seen in Scripture is then viewed as not proper to God. Something else behind this witness is essential to God, so that his attributes lose their reality in favour of the essence. However, the Father of Jesus Christ has empathy with human beings requiring that Jesus suffered and died in humans' stead in order to allow God to reconcile humans with him (Solivan 1998:47-48). Instead of an immutable, perfect and apathetic God, as Barth maintains traditional theism created when it pictured God in terms borrowed from ancient Stoicism and Neo-Platonism, what is needed is that God's attributes be redefined through the lens of Jesus Christ and the work of the Spirit in the believer's life (Migliore 1983:74). The power of his almightiness, for instance, should be reflected through the lens of Christ's suffering on the cross where the power of God becomes weakness that challenges

19.In this regard, Pentecostal speaking in tongues serves as a prayer and worship 'metalanguage' that allows the worshipper to enter God's presence and worship him intuitively and affectively, bypassing the intellectual for the moment. Speaking him intuitively and affectively, bypassing the intellectual for the moment. Speaking and singing in tongues allows for
human being (McGee 2007:10). 
and restructures our ideas of power in a secularist sense (Moltmann 1974:12). Such redefinition is an essential task that Pentecostal theology should undertake as the basis of its God talk

We cannot do anything else but to talk of God in faithfulness to Scripture's witness about him and the reality of our contemporary experience, but it should be remembered that language can never encompass him, as argued already. Although he interacts with us, his creatures, as Creator he is totally different from anything human beings can propose. He enters space and time to encounter us in his incarnation, yet he is beyond time and space in eternity, a concept that does not make sense from our point of observation (Noel 2007:63). The transcendent God meets human beings in his immanence but he remains a mystery that our mind can never contain.

A further characteristic of Pentecostal theology, it is suggested, is that it should use the philosophical language of dialectic, as has been intimated above in terms of the utility of paradoxical terms to describe God. From the start, Pentecostal experience can only be called Christian if it draws its interpretation from the Bible as the Word of God. In fact, it is the dialectic between the (given) narratives of the Bible and the liturgically celebrated (received) narratives of the church that brings meaning in the here and now (Leoh 2007:103; Plüss 2003:3). Dialectic allows one to speak of two or more, usually contradictory, truths while not negating either one. Barth and Brunner use this method to emphasise the qualitative difference between what can be said about God and who he really is (Brunner 1931:6-7). ${ }^{20}$ Although dialectic intimidated the early Barth to say too little about God, later on he used it as a tool to describe the attributes of God in terms of their contradictions (mercy vs. justice, love vs. punishment, unity vs. omnipresence). God is the hidden one who reveals (something of) himself. Dialectic in describing what we can know about God allows some glimpses of him, but at the same time it suggests that we can never exhaust his being by what we say about him (Karkkainen 1998:88). Speech about God can be nothing else but provisional and conditional, because it is inadequate to encompass God with human words (Cross 2000:45). Words are often related to experience, but they are not the same thing. Words explain and describe experience, and in doing so, they provide models that can help people assess their own experience. Words situate experiences within a broader understanding of who God is, how the world is put together and what it means to be human. These uses of words taken together constitute the field of theology. Pentecostals also use theological words to make sense of their faith, but they are suspicious of words. The movement is to some degree a protest against too much reliance on words, or rather the use of religious words

20. Barth and Brunner's dialectical theology is based on the view that there is neither an identity between thought and being (as in Platonic idealism) nor a direct correspondence (as in realism), but instead a cleavage, which is the result not of finitude per se but of sin. This cleavage is overcome in the paradoxical entry of eternity into time, that is, in the incarnation of the infinite God in Jesus of Nazareth. All contradictions in human thinking concerning God and his relationship to us have their centre in this absolute paradox (Kierkegaard), which is incomprehensible to human reason (Bloesch 2005:76) without religious experience to back it up. Too much words, they suspect, might drain the power from their own experiences of the Spirit (Jacobsen 2006:5-6).

The living, interacting God is personal, as experienced in his incarnation where he stoops down and mingles with human beings. But his works do not exhaust his person and therefore Pentecostals worship the One living in a realm beyond human capacity to understand as the mighty God whose mere words create worlds (Alvarsso 2007:193). Dialectic helps to view God more holistically as the indescribable Reality that also exists outside creation.

Pentecostals worship the God of the Bible, the One who is at hand, and far away so that no one can hide from him in secret because he fills both heaven and earth (Jr 23:23). God had chosen some human beings from the beginning for salvation (2 Th 2:13b); before the foundation of the world he predestined them to adoption as sons through Jesus Christ (Eph 1:4-5). At the same time, human beings may choose or reject salvation - if you confess with your mouth Jesus as Lord and believe in your heart that God raised him for the dead, you will be saved ( $\mathrm{Rm} \mathrm{10:9).} \mathrm{On} \mathrm{one} \mathrm{hand,} \mathrm{the} \mathrm{Bible}$ clearly teaches monotheism, that there is one and only one God and that he is one (Dt 6:4). Yet, the Bible also teaches that the one God consists of three persons (Mt 28:19; 2 Cor 13:14). Another paradox is the nature of Jesus Christ with some passages clearly teaching that he is fully human (e.g. Rm 1:2-3), while other passages teach that Jesus is fully divine (Mt 1:23; Col 2:9). These paradoxes need the logic of dialectic to make enough sense that it encourages the student of the Bible to bow in worship before God. While Pentecostal theologians strive for rationality in theological formulation, they must choose revelation over the finite restrictions of human logic (McRoberts 2007:146).

What is important in Pentecostal theology is that abstract philosophical considerations of God be exchanged for the incarnation because through Christ God grants eternal life (Shaull 1998:8). The incarnation demonstrates that God desires relationship with his creatures, placing theology within the dynamic realm of relationality. However, God's transcendence may not be ignored and should also be considered, but then not in terms of abstractions but as God beyond our language, the God before whom we stutter and stammer, requiring paradox to say something sensible about him (Holm 2003:24). The witness of Scripture and the testimony of the Spirit in our experience require that both aspects be addressed (allowing Dela Cruz 2010:100 to speak of 'testimonial hermeneutics').

\section{Conclusion}

In bringing their own ethos to the theological table, Pentecostals regard the Bible as the inspired Word of God with authority for their lives. But they qualify that statement, that encounters with God within the faith community in ways similar to those recorded in the Bible is conditional for understanding and interpreting biblical accounts. 
Pentecostals need to develop a perspective on the allinclusive difference made by their experience of God in all areas of their lives. The two elements conditional for good theology are the interpretation and appropriation of the biblical narrative, and God's Spirit driving home the truth contained in that narrative. In talking about God, Pentecostals view him in trinitarian terms, as they experience him in his interacting with human beings. Trinitarian theology is per se a theology of relationships, concerned with communion and love, forgiveness and courtesy. God is viewed as a being whose fundamental feature is loving relationality. God cannot be contained in absolutist and unchangeable categories and language can never adequately express him. It is suggested that the philosophical language of dialectic be used to describe God. Dialectic allows one to speak of two or more, usually contradictory, truths while not negating either one. The living, interacting God is personal, as experienced in his incarnation where he stoops down and mingles with human beings until present times. His works do not exhaust his person and therefore Pentecostals worship the transcendent One living in a realm beyond human capacity to understand as the mighty God whose mere words create worlds. Dialectic helps to view God more holistically as the indescribable Reality that also exists outside creation.

\section{Acknowledgements}

\section{Competing interests}

The author declares that he has no financial or personal relationships which may have inappropriately influenced him in writing this article.

\section{References}

Althaus, P., 1966, The theology of Martin Luther, transl. R.C. Schultz, Fortress, Philadelphia.

Alvarez, M.O., 2014, 'Integral mission in contemporary perspective: Exploring an appropriate lodel of mission for the Pentecostal churches with special reference to Honduras', PhD dissertation, Middlesex University.

Alvarsso, J.-A., 2007, 'The Bible, Pentecostalism, and "magic", Journal of the European Pentecostal Theological Association 27(2), 183-196. https://doi.org/10.1179/ jep.2007.27.2.009

Archer, K.J., 2004, A Pentecostal hermeneutic for the twenty-first century: Spirit, scripture and community, T\&T Clark, London/New York.

Arrington, F.L., 1988, 'Hermeneutics, historical perspectives on Pentecostal and charismatic', in S.M. Burgess \& G.B. McGee (eds.), Dictionary of Pentecostal and charismatic movements, pp. 376-389, Zondervan, Grand Rapids, MI.

Asamoah-Gyadu, J.K., 2012, 'Learning to prosper by wrestling and by negotiation: Jacob and Esau in contemporary African Pentecostal hermeneutics', Journal of Pentecostal Theology 21, 64-86. https://doi.org/10.1163/174552512x633303

Barth, K., 1957, Church dogmatics: The doctrine of God. II, G.W. Bromiley \& T.F. Torrance (eds.), T\&T Clark, Edinburgh.

Barth, K., 1979, Evangelical theology, Warfield Lectures, EVZ-Verlag, Zürich.

Becker, M., 2004, 'A tenet under examination: Reflections on the Pentecostal hermeneutical approach', Journal of the European Pentecostal Theological Association XXIV, 30-48. https://doi.org/10.1179/jep.2004.24.1.004

Bloesch, D.G., 2005, A theology of Word \& Spirit: Authority \& method in theology, InterVarsity, Downers Grove.

Bowdle, D.N., 2000, 'Informed Pentecostalism: An alternative paradigm', in T. Cross \& W. Powery (eds.), The Spirit and the mind: Essays in informed Pentecostalism, pp. 9-19, University Press of America, Lanham, MD.

Brown, C., 1974, Philosophy and the Christian faith, InterVarsity, Downers Grove.

Brueggemann, W., 1997, Theology of the Old Testament: Testimony, dispute, advocacy, Fortress, Minneapolis, MN.

Brunner, E., 1931, The Word and the world, Charles Scribner's Sons, New York.

Byrd, J., 1993, 'Paul Ricoeur's theory and Pentecostal proclamation', Pneuma: The Journal of the Society for Pentecostal Studies 15(2), 203-214. https://doi. org/10.1163/157007493X00176
Cargal, T., 1993, 'Beyond the fundamentalist-modernist controversy: Pentecostals and hermeneutics in a postmodern era', Pneuma 15(2), 163-187. https://doi. org/10.1163/157007493X00158

Castelo, D., 2004, 'Tarrying on the Lord: Affections, virtues and theological ethics in Pentecostal perspective', Journal of Pentecostal Theology 13(1), 31-56. https:// doi.org/10.1177/096673690401300103

Cross, T.L., 2000, 'The rich feast of theology: Can Pentecostals bring the main course or only the relish?', Journal for Pentecostal Theology 16, 27-47. https://doi. org/10.1177/096673690000801602

Dela Cruz, R.G., 2010, 'Preaching among Filipino Pentecostals and exposition through testimonial hermeneutics: A positive contribution of the PGCAG to evangelicalism in the Philippines', Asian Journal for Pentecostal Studies 31(1), 98-123.

Ellington, S.A., 1996, 'Pentecostalism and the authority of Scriptures', Journal of Pentecostal Theology 9, 16-38. https://doi.org/10.1177/096673699600400902

Ellington, S.A., 2001, 'History, story, and testimony: Locating truth in a Pentecostal hermeneutic', Pneuma: The Journal of the Society for Pentecostal Studies 23(2), 245-263. https://doi.org/10.1163/157007401X00195

Erickson, M.J., 1985, Christian theology, Baker, Grand Rapids, MI.

Ervin, H.M., 1979, 'Hermeneutics: A Pentecostal option', in J.L. Sandidge (ed.), The Roman Catholic Pentecostal Dialogue, Vol. 2, pp. 100-121.

Fries, H., 1996, Fundamental theology, Catholic University of America Press, Washington, DC.

Gilkey, L., 1961, 'Cosmology, ontology, and the travail of biblical language', Journal of Religion 41, 194-205.

Goldingay, J., 1997, 'Biblical story and the way it shapes our story', Journal of the European Pentecostal Theological Association 17, 5-15. https://doi.org/10.1179/ jep.1997.17.1.002

Grenz, S., 1993, Revisioning evangelical theology: A fresh agenda for the 21st century, InterVarsity, Downers Grove.

Holm, R., 2003, 'Cadences of the heart: A walkabout in search of Pentecostal preaching', Didaskalia Fall 7(1), 13-27.

Horton, S. (ed.), 1994, Systematic theology. Logion, Springfield, IL.

Huckle, J.S., 2009, 'The contemporary use of the gift of prophecy in gatherings of Christians in comparison with their use in the 20th century', Journal of the European Pentecostal Theological Association XXIX(1), 72-85. https://doi. org/10.1179/jep.2009.29.1.007

Jacobsen, D. (ed.), 2006, A reader in Pentecostal theology: Voices from the first generation, University Press, Bloomington, IN.

Johns, C.B., 1995, 'The adolescence of Pentecostalism: In search of a legitimate sectarian identity', Pneuma: The Journal of the Society for Pentecostal Studies 17, 3-17. https://doi.org/10.1163/157007495X00020

Johns, K.D., 2007, The Pentecostal paradigm: A seductive paradise, Xlibris, Pittsburgh, PA.

Johnson, L.T., 1998, Religious experience in earliest Christianity: A missing dimension in New Testament studies, Fortress, Minneapolis, MN.

Joubert, S., 2013, 'Not by order, nor by dialogue: The metanoetic presence of the kingdom of God in a fluid new world and church', Acta Theologica 33(1), 114-134. https://doi.org/10.4314/actat.v33i1.6

Karkkainen, V.-M., 1998, 'Pentecostal hermeneutics in the making on the way from fundamentalism to postmodernism', Journal of the European Pentecosta Theological Association 18, 76-115. https://doi.org/10.1179/jep.1998.18.1.006

King, G.W., 2008, 'Streams of convergence: The Pentecostal-fundamentalist response to modernism', PentecoStudies 7(2), 64-84.

Köstenberger, A.J., 2012, 'Invitation to biblical interpretation \& the hermeneutical triad: New hermeneutical lenses for a new generation of bible interpreters', Criswell Theological Review 10(1), 3-12.

LaCugna, C., 1991, God for us: The Trinity and Christian life, HarperSanFrancisco, San Francisco, CA.

Land, S., 1993, Pentecostal spirituality: A passion for the kingdom, JPTSup I, Sheffield Academic Press, Sheffield.

Leoh, V., 2007, 'Eschatology and pneumatic preaching with a case of David Yongg Cho', Asian Journal for Pentecostal Studies 10(1), 101-115.

Lewis, P.W., 2001, 'Reflections of a hundred years of Pentecostal theology', paper presented at the 9th Annual William Menzies Lectureship, Asia Pacific Theological Seminary, in Baguio, Philippines, 12th January.

Marsden, G., 2006, Fundamentalism and American culture, Oxford University Press, Oxford.

McClean, M.D., 1984, 'Toward a Pentecostal hermeneutics', Pneuma: The Journal of the Society for Pentecostal Studies 6(2), 35-55. https://doi. org/10.1163/157007484X00086

McGee, G.B., 2007, 'Brought into the sphere of the supernatural: How speaking in tongues empowered early Pentecostals', Encounter 4(1), 1-16.

McRoberts, K.D., 2007, 'The holy trinity', in S. Horton (ed.), Systematic theology, rev. edn., pp. 140-172, Logion, Springfield, IL.

Mei, J.N.M., 2001, 'Die verstaan van die boodskap van Miga binne ' $n$ Pinksterhermeneutiese raamwerk, met besondere verwysing na Miga 2, 1-13', MA Dissertation, University of South Africa.

Menzies, W., 1979, 'Synoptic Theology: An essay on Pentecostal hermeneutics', Paraclete 13(1), 14-21.

Migliore, D., 1983, The power of God, Westminster, Philadelphia, PA. 
Migliore, D., 1991, Faith seeking understanding: An introduction to Christian theology, Eerdmans, Grand Rapids, Ml.

Moltmann, J., 1974, The crucified God: The cross of Christ as the foundation and criticism of Christian theology, transl. R.A. Wilson \& J. Bowden, Harper \& Row, New York.

Noel, B.T., 2007, 'Pentecostal and postmodern hermeneutics: Comparisons and contemporary impact', DTh Dissertation, University of South Africa.

Pinnock, C.H., 1990, Tracking the maze: Finding our way through modern theology from an Evangelical perspective, Harper, San Francisco, CA.

Pinnock, C.H, 2000, 'Divine relationality: A Pentecostal contribution to the doctrine of God', Journal for Pentecostal Theology 16, 2-26. https://doi org/10.1177/096673690000801601

Plüss, J.-D., 2003, 'Religious experience in worship: A Pentecostal perspective', PentecoStudies 2(1), 1-21. Paper presented at the 6th WARC/Pentecosta Dialogue Amsterdam, May 17-22, 2002.

Railey, J.H. \& Aker, B.C. (eds.), 2007, 'Theological foundations', in S. Horton (ed.), Systematic theology, rev. edn, pp. 40-60, Logion, Springfield, IL.

Ruthven, J., 1969, 'The cessation of charismata, Part one: A survey of a prevailing viewpoint', Paraclete 3(2), 1-11.

Schaeffer, F., 1990, The triology, Crossway, Wheaton, IL.

Shaull, R., 1998, 'When can the mainline learn from Pentecostals about Pentecost preaching?', Journal for Preachers Lent 21(4), 8-14.

Siekawitch, L.D., 2009, 'Calvin, Spirit, Communion and the Supper', Journal of the European Pentecostal Theological Association 2, 14-35. https://doi.org/10.1179/ jep.2009.29.2.004
Solivan, S., 1998, The Spirit, pathos and liberation: Toward an Hispanic Pentecostal theology, JTPSup 14, Sheffield Academic Press, Sheffield.

Stevens, B., 2006, “'Up, up and away": Pentecostal preaching and the manic defence', Asian Journal for Pentecostal Studies 9(2), 284-294.

Taylor, G.F., [1907]2006, 'The Spirit and the bride', in D. Jacobsen, A reader in Pentecostal theology: Voices from the first generation, pp. 58-66, Indiana University Press, Bloomington, IN.

Tollefsen, C., 2014, 'Morality and God', Quaestiones Disputatae 5(1), 47-60. https:// doi.org/10.5840/qd2015516

Ukpong, J.S., 1984, 'Current theology: The emergence of African theologies', Theological Studies 45, 501-536. https://doi.org/10.1177/004056398404500305

Van der Laan, C., 1989, 'The theology of Gerrit Polman: Dutch Pentecostal pioneer', Bulletin of the European Pentecostal Theological Association VIII(1), 13-33.

Volf, M., 1998, After our likeness: The church as the image of the Trinity, Eerdmans, Grand Rapids, MI.

Williams, J.R., 1988, Renewal theology, vol. 1, Zondervan, Grand Rapids, MI.

Yong, A., 1998, 'Whither systematic theology? A systematician chimes in on a scandalous conversation', Pneuma: The Journal of the Society for Pentecostal Studies 29, 89-93. https://doi.org/10.1163/157007498x00072

Yong, A., 2002, Spirit-Word-Community: Theological hermeneutics in Trinitarian perspective, Ashgate, Burlington, VT.

Yong, A., 2015, 'Proclamation in/of the Spirit: Toward a pneumatological theology of preaching', The Living Pulpit Summer, 34-38.

Zizioulas, J., 1997, Being as communion: Studies in personhood and the church, St Vladimir's Seminary Press, Crestwood, NY. 